https://doi.org/10.48009/2_iis_2009_623-639

\title{
EXAMINING THE UNDERPINNINGS OF ORGANIZATIONAL CULTURE AND ORGANIZATIONAL SYSTEMS: A LITERATURE REVIEW
}

\author{
Dr. Marguerite E. Barta, Kaplan University, mbarta@Kaplan.edu
}

\begin{abstract}
Through a literature review, this paper examines the underpinnings of organizational culture and organizational systems, as well as the ways in which these organizational systems and cultures have morphed into a new entity by virtue of the influence of the Internet. The Internet is a catalyst for change, and within successful business practices, these imposed changes must be recognized, respected, and anticipated.
\end{abstract}

Keywords: Ethnography, organizational systems, organizational management, organizational behavior, business culture, eculture, change, e-change, customer relationship management (CRM), customercentric/student-centric

\section{INTRODUCTION}

This literature review includes an introduction to ethnography; a review of the research on organizations, organizational systems, the evolution of organizational management, organizational behavior,

business culture, e-culture, change, echange, customers of the $21^{\text {st }}$ century, customer relationship management (CRM), a customer-centric/student-centric business view; and the implications of these topics for business and e-business in the $21^{\text {st }}$ century.

\section{ETHNOGRAPHY}

An ethnographic study "seeks to capture, interpret, and explain how a group, organization, or community; lives, experiences, and makes sense of their lives and their world" (Robson, 2002, p. 89). Ethnography is the art and science of describing a group or a culture (Fetterman, 1998). The researcher who is interested in ethnography

studies an intact cultural group in a natural setting over a prolonged period by collecting primarily observational data (Creswell, 1998). Ethnographic research occurs when a researcher enters into an intact cultural group within its natural setting and studies that cultural group. Anthropologists believe that the primary function of ethnography is cultural interpretation. "Cultural interpretation is the researchers' ability to describe what has been observed (heard and seen) within the framework of the social group's view of reality" (Fetterman, 1998, p. 18). Van Maanen (1988) introduced three accepted types of ethnography: realist tales, confessional tales, and impressionist tales. These three types of ethnography reside beside a fourth type of evolving ethnography, one that includes critical tales, formal tales, literary tales, and jointly told tales.

Realist tales are detailed realistic accounts of the culture of a group of people who have a common interest or purpose. Van Maanen (1988) stated that realist tales are "by far the most prominent, familiar, prevalent, popular, and recognized form of ethnographic reporting" (p. 45). Four conventions 
differentiate realist tales from all the other recognized tales: experiential authority, typical forms, the natives' point of view, and interpretive omnipotence. These four conventions are important to the researcher and the reader because contrary to any other form of ethnography, they are the quintessential voice of the realist tale.

Confessional tales are created from the heart, soul, and being of the participants and the researchers. Confessional tales absorb the true self; the inner self; and the secret, unrevealed self. Confessional tales could be the voice of the Holocaust survivor translated into written form by the researcher, or they could be the resounding screams of the people of Hiroshima placed into reality for future generations. According to Van Maanen (1988), the confessional tale has three conventions: personalized author, the fieldworker's point of view, and naturalist.

Ethnography places the researcher in the cultural environment of the participant. Therefore, as the researcher intently observes and listens to the participant, the confessions of the participant become a part of the researcher's own experience. Thus, the personalization of the confession becomes a part of the equation as the experience is codified and transcribed onto the written page. The fieldworker's view is preconceived reality dictated by the ethnographer's own past experiences and perceived reality. Van Maanen (1988) expressed this as a psychological symmetry with the event; thus, the experience is owned by the researcher, so the recount of the event becomes autobiographical. Finally, the naturalist phenomenon understands and acknowledges the weakness of humankind and the slight imperfections that exist within each of us. This recognized frailty then becomes an anticipated and accepted part of the researcher's work (Van Maanen, 1988).

The third accepted construct is that of impressionist tales, which follow the style of great Impressionist artists from the late $19^{\text {th }}$ century. Artists such as van Gogh, Monet, Pissarro, Renoir, Sisley, Cézanne, Degas, and Monet are revered for their unique artistic style (Khan \& Conte, n.d.). Similarly, the ethnographic Impressionist's words are equally recognized in the tone of the Impressionist artist's flair. The Impressionist researcher's "words, metaphors, phrasings, imagery, and most critically, the expressive and expansive recall of the fieldwork experience" (Van Maanen, 1988, p. 102) are the artists' oil paints. Once the oil paints are laid onto the canvas, so, too, are the Impressionist researcher's words placed onto the page. The Impressionistic style of recording an accurate and objective snapshot of time and experience is transported from the early Impressionist artists to the Impressionist researcher of today (Van Maanen, 1988).

The fourth and final ethnographic form is an evolution of the former three ethnographic forms. It contains its own four new styles: critical tales, formal tales, literary tales, and jointly told tales. Van Maanen (1988) defined these as the following:

Critical tales - representation of a social structure as seen through the eyes of disadvantaged groups in advanced (and not-so-advanced) capitalist countries... formal tales the formalists of ethnography are out to build, test, generalize, and otherwise exhibit theory.... The formalists of ethnography are interested in ethno methodology, semiotics, symbolic interactionism, conversational analysis, ethno semantics, sociolinguistics, ethnoscience, various forms of 
structuralism and so forth.... Literary tales -journalist work that use intense and sustained fieldwork as a way of coming to terms with the social worlds they investigate..., and jointly told tales which are the production of jointly authored texts (fieldworker and native) in a way that opens up for readers the discursive and shared character of all cultural descriptions (pp. 128-136)

\section{THE ORGANIZATION AND ITS SYSTEMS}

An organization is a collective group of people who work toward a common goal or purpose. Organizations are unique because they facilitate the performance of tasks that would not ordinarily be within the reach of single participants. Scott and Davis (2007) restated this same concept by noting, "An organization is a social structure created by individuals to support the collaborative pursuit of specified goals" (p. 11).

Organizations may be big or small, and for profit or not for profit, and they will have a reason for existing, such as a goal and/or a purpose. Organizations usually have a mission statement, a vision statement, or a goal statement; they also may have a purpose statement. Organizations facilitate the retail and wholesale provision of goods, tangible and intangible products, and services that fulfill the wants, needs, desires, and value perceptions of their internal and external customers and the organization's stakeholders.

Efficient and effective performance levels in an organization translate into the success or failure of the organization. Organizations influence, economically impact, and serve the surrounding community. In summary, organizations often start from an image and become a machine built for accomplishing goals either as a small society with a social structure and culture or as an organism making its way through a resource environment (Moore, as cited in Scott \& Davis, 2007; Schermerhorn, 2008).

A central base of divergence for organizational analysts and researchers is the division of organizations into three distinct categories. The determining factors for these three categories are fundamental differences, distinctive features, and characteristics of the organization. The three categories are the rational organizational system, the natural organizational system, and the open organizational system (Scott \& Davis, 2007).

\section{Rational Organizational System}

Scott and Davis (2007) defined the rational organizational system as "collectives orientated to the pursuit of relatively specific goals and exhibiting relatively highly formalized social structures" (p. 29). In addition to this definition, Scott and Davis explained that the rational organizational system has two structural features. According to the description of Feature 1,

Organizations are collectives orientated to the pursuit of relatively specific goals. They are purposeful in the sense that the activities and interactions of participants are coordinated to achieve specific goals. Goals are specific to the extent that they are explicit, clearly defined, and provide unambiguous criteria for selecting an amount of alternative activities. (Scott \& Davis, 2007, p. 28)

This is the most positivistic of the organizational paradigms based upon its description, its theory, and its preferred research methodology. In regard to Feature 
2,

Organizations are collectivities that exhibit a relatively high degree of formalization. The cooperation among participants is "conscious" and "deliberate"; the structures of relations within the organization are explicit. A structure is formalized to the extent that the rules governing behavior are precise, explicit, and formulated to the extent that the roles and role relations are prescribed independently of the personal attributes and relations of individuals occupying positions in the structure. (Scott \& Davis, 2007, p. 29)

\section{Natural Organizational System}

Scott and Davis (2007) defined a natural organizational system as "collectives whose participants are pursuing multiple interests, both disparate and common, but who recognize the value of perpetuating the organization as an important resource"

(p. 30). This paradigm hints at the participants' meaning of the organizational system and is more easily understood through symbolic interpretivism and its corresponding methodologies.

\section{Open Organizational System}

The third organizational system is the open organizational system, which Scott and Davis (2007) defined as "organizations that are congeries of interdependent flows and activities linking shifting coalitions of participants embedded in wider materialresource and institutional environments" (p. 32). The postmodern perspective might be used in this view of organizations, although interpretivism also could be used in understanding this paradigm.

\section{CLASSICAL APPROACHES TO}

\section{ORGANIZATIONAL MANAGEMENT}

The classical approaches dominate the history of organizational management; therefore, discussion of the rational systems within the classical approaches adds clarity to this literature review. The three core classical approaches to organizational management are scientific management, administrative principles, and the bureaucratic organization.

Taylor (1911, as cited in Schermerhorn, 2008) pioneered scientific management, a principle that was complemented by the motion studies of Frank and Lillian Gilbreth. The administrative principles approach began with the 1916 work of Henry Fayol and culminated with the work of Henry Gantt and his well-known Gantt Chart. Finally, the last classical approach is represented with the work of Max Weber and the bureaucratic organization.

\section{BEHAVIORAL MANAGEMENT APPROACHES TO \\ ORGANIZATIONAL MANAGEMENT}

Following the classical approaches to organizational management are the behavioral management approaches. The behavioral management approach to organizational management was clearly defined by the works of Mary Parker Follett, Elton Mayo and the Hawthorne Studies, Chester Barnard, Abraham Maslow, Frederick Herzberg, Douglas McGregor, and William Ouchi. These pioneers, coupled with their ideas, concepts, and theories, provided the foundation for today's business environment, organizational management, and science of organizational behavior.

\section{ORGANIZATIONAL BEHAVIOR}

“Organizational behavior $(\mathrm{OB})$ is a field of 
study that investigates the impact that individuals, groups, and structure have on behavior in organizations for the purpose of applying such knowledge toward improving an organization's effectiveness" (Robbins \& Judge, 2007, p. 9). The behavior of people at work is divided into three determinates of OB: individual behavior, group behavior, and structural behavior. The study of $\mathrm{OB}$ concentrates on the effect of organizational structure; the behavior of the individuals and groups of people in the organization; and how the efficacy, success, and/or failure of the organization is impacted (Robbins \& Judge, 2007).

$\mathrm{OB}$ is an applied behavior science that is rooted in the four behavior disciplines of psychology, social psychology, sociology, and anthropology. The bombardment of people and businesses by constant change and $\mathrm{OB}$ has created few absolutes and means that the organizational culture, $\mathrm{OB}$, and individual behavior are best expressed using contingency variables. The world is complex, intricate, and complicated; therefore, the science of organizational behavior is an adaptable entity created to explain and examine the culture of organizations, and to manage change within the organization (Robbins \& Judge, 2007).

\section{Organizational Culture}

Organizational culture is a common property of a group of people that is ambiguous and invisible to tacit observation. Culture defines and guides people to act in certain ways within specific circumstances. The expression of culture within an organization is manifested in how people act and react to stimuli, how they dress, the work setting of the organization, the artifacts and symbols of the organization, the value system of the organization, the rites and rituals of the organization, the heroes of the organization, and the shared stories and experiences within the organization (Schermerhorn, 2008).

\section{E-culture}

E-culture is the human side of the global information era; it is the heart and soul of the new economy (Kanter, 2001). E-culture is the application of information and communication technology for entertainment, culture, education, and leisure (Fleischmann \& Strauss, 2005). Eculture is a "virtual" displacement of culture in an organization. E-culture is a paradigmic change brought forth by the intrusion of the World Wide Web and the Internet, and by the inclusion of e-business into the business world. This displacement of culture and the changes required were discussed by Kanter, who asserted that e-culture is a "new way of working and it is the human side of the global information era, the heart, and soul of the new economy" (p. 6).

Embracing the new e-culture leads to success, whereas ignoring technology and eculture puts a business in peril. E-culture means leading organizations in new ways of conducting tasks and work methods. For survival in the new e-world, organizations must recognize new truths about business:

E-culture is about creative destruction, e-culture is like living in a glass house under a huge spotlight that's always on $24 / 7$, e-culture is superficial - in good ways, and if done right, e-culture protects against armed combat, e-culture is made up as you go along, e-culture is full of paradoxes, and e-culture can be a great deal of fun. (Kanter, 2001, p. 7)

\section{Change}


Futurist Isaac Asimov clearly placed the concept of change into perspective with the following comment:

It is change, continuous change, inevitable change, that is the dominant factor in society today. No sensible decision can be made any longer without taking into account not only the world as it is, but the world as it will be. (as cited in Bartelby.com, 1996, If 1)

Survival in the global village requires nimble organizations that are ready to adapt and change as necessary. Futurist Kanter (1983) stated that "organizations which either fail to understand the need or are inept in their ability to deal with it will fail and fall behind, if they survive at all" (p. 38).

Organizations that are proactive and ready to change are learning organizations. Senge (1990) argued that the successful organization of the future is the learning organization, which is an organization that is "continually expanding its capacity to create its future" (p. 14). According to Senge, in a learning organization, adaptive learning is in response to change, whereas generative learning "enhances our capacity to create" (p. 14). Learning is the answer to change.

The "catalysts and responsibilities for change reside at many levels, including global competition, patterns of world trade, economic pressures, political sensibilities, the labor force, demographics, culture, technological change, and customer expectations" (Kanter, 1983, p. 3).

Recognition of these change factors is critical to organizational success. Kanter (1983) expressed this sentiment succinctly as "the degree to which the opportunity to use power efficiently is granted to or withheld from individuals is one operative difference between those companies which stagnate and those which innovate" (p. 18). Change is inevitable, and technology has brought intense change to society. Recognizing these changes, accepting that change is inevitable, and adapting to the new e-cultures and e-ways are essential to running successful customer-centric ebusinesses. The catalyst of this paramount change from organizational culture to eculture is technology. Therefore, understanding the "how," "what," and "where" of technology and the technology revolution is fundamental.

\section{E-change}

Change has mutated to e-change, precipitated by technology, computers, the Internet and the World Wide Web. The Internet is

An interconnected network of thousands of networks and millions of computers (sometimes called host computers or just hosts) linking businesses, educational institutions, government agencies, and individuals.... The word Internet is derived from the word internetwork, or the connecting together of two or more computer networks. (Laudon \& Guerico Traver, 2007, p. 114)

The World Wide Web is

One of the Internet's most popular services, providing access to over 8 billion web pages, which are documents created in programming language called HTML that can contain text, graphics, audio, video and other objects, as well as hyperlinks that permit users to jump easily from one page to another. (Laudon \& Guerico Traver, 2007, p. 114)

Technology, computers, the Internet, and the 
World Wide Web are an accepted part of survival and success in the business world. The acceptance of these changes in the business world means that organizations must exist and function competitively and profitably in the virtual world of cyberspace. New words and terminology have entered the lexicon of the business world; instead of a business entrepreneur considering the marketplace of the past, the marketspace, which is an electronic space where business occurs, is now the center of attention (Harrell, 2002).

The effective business leader must listen to, consider, and answer the voice of the customer. That same leader needs and wants to hear how the customer's voice translates into the wants, needs, opinions, perceptions, and desires of the $21^{\text {st }}$-century customer (Foster, 2001). The voice of the customer is the exact key to the lock for businesses in this new virtual frontier of the World Wide Web and the Internet. The actual codification and manipulation of the knowledge from the "voice of the customer" translates into quality function deployment (Foster, 2001).

The tools for this task are management information systems (MISs) and their subsystems of information-reporting systems (IRSs). MISs are computer-based systems that provide information and support for effective managerial decision making (Daft, 2003). IRSs are a subset of the MIS function. The IRS is the actual translation of information from within the system into data. The compiled data, which are raw facts and observation, are now knowledge and information, which are data made useful and meaningful for decision making (Schermerhorn, 2008), that are entered and sorted into reports, which are then supplied to management and decision makers to support the making of well- informed business decisions (Daft, 2003).

Some of the other tools available to management for use in knowledge management are decision support systems, executive support systems, and groupware. All of these processes rely upon transactionprocessing systems, which are the process control systems that implement the efficient codification and management of knowledge into operation information systems (Daft, 2003). This all translates into an office automation system that consists of the hardware and software systems within the company that handle the tasks of publishing and distributing information (Daft, 2003).

These are tools that have become commonplace in the virtual workplace.

Culmination of these systems and processes brings us to focus upon the marketing and business process design of CRM.

CRM is the organizational driving force for innovative, visionary, goal-oriented organizations of the $21^{\text {st }}$ century to become truly customer-centric. Having insight into the technological and human resources of an organization can facilitate the profitgenerating function of the organization because it more readily identifies the behavior of customers and subsequently addresses the customers' wants, needs, and demands.

\section{CUSTOMER-CENTRIC ORGANIZATIONS}

Customer-centric organizations understand, embrace, and live with an operating and organization model that focuses on the customers. Customer-centric organizations work diligently to increase customer satisfaction and loyalty, and to understand what customers want and value, all while increasing profitability and perpetuating the growth of the organization. Customer- 
centric organizations adjust, hone, and tailor their business streams, which include their product, development, demand generation, production and scheduling, supply chain, and customer care, with the organizational goal of delivering the greatest value to the best customers for the least cost (Kocourek et al., 2004). Customer-centric organizations are comprised of workforces that are devoted to utilizing company-wide, technology-based, internal customer information systems and are willing to make a strong commitment to serving the customers (Wreden, 2005).

\section{CUSTOMERS OF THE 21ST CENTURY}

The customers of the $21^{\text {st }}$ century control or own the leaders of the business, the customers of the $21^{\text {st }}$ century control or own the employees of the business, and the customers of the $21^{\text {st }}$ century control or own the business because the customers of the $21^{\text {st }}$ century hold the potential success or failure of the business in their firm grip. Customers demand and expect fast, efficient, and effective service instantaneously. Customers anticipate and expect that all of their personal information, likes and dislikes, and special preferences are recognized and efficiently turned into action. Establishing customer value means that the customers' dreams or desires are served professionally, quietly, proficiently, and efficiently, always catering to the customers' wants, needs, desires, and dreams

The customers of the $21^{\text {st }}$ century know that the power of information and intense competition affords them the advantage that facilitates their demands. The customers of the $21^{\text {st }}$ century demand personalized service, and they demand to speak to the person in charge so they may get the best deal. They not only demand everything but also want the companies they do business with to change to meet their desires and whims (Galbraith, 2005). The success of a business ultimately resides in the carefully maintained and groomed connections that businesses establish with their customers. This fundamental connection mandates the establishment of virtual communities. The proliferation of online interactions between customers and organizations has profoundly changed the business landscape into a customer-centric model within a cyberenvironment (Hagel \& Armstrong, 1997).

\section{CUSTOMER RELATIONSHIP MANAGEMENT (CRM)}

The business-marketing tool of CRM originated as the brainstorm of Siebel Systems cofounders Tom Siebel and Pat House. In July 1993, they built a salesinformation system grounded within integrated and expanded customer-service software. Among Siebel Systems's early adopters/customers were Brock Control Systems and Sales Technologies; Ford Motor Company; Citigroup, Inc.; and Marriot International, Inc. According to Adam Kraber, of PriceWaterhouseCooper, Siebel Systems practiced the marketing tool of CRM first. Siebel Systems last release of a CRM solution, Siebel 99, flagships over 117 applications for sales, service, and the incorporation of multiple vertical markets. House and Siebel stated that Siebel Systems has clearly defined the CRM market (Center for Management Information Technology, Sweat, 1999).

CRM is a business and a marketing knowledge management tool that empowers a business to customer-centricity and ultimately to success when it is utilized 
correctly. It is a fundamental change in the culture and the operation systems of the organization that goes beyond the automation of functions because it drives the organization to answer the call of the customers and become customer centric. CRM is a strategy that uses information, including the wants and needs of the customers, to establish rapport with the customers and engender a dedicated, stronger relationship with individual customers as well as long-term business partnerships and vendor/business relationships (Dickie, 1998).

Fathy (1999) commented:

CRM is all about understanding the customers' needs and leveraging this knowledge to increase sales and improve service. CRM blurs the boundaries between sales and service, and unifies a company's activities around the customer. The overarching goal is to increase customer share and customer retention through customer satisfaction. (II 1)

[CRM] is "the process of learning as much as possible about customers and doing everything you can to satisfy them - or even exceed their expectations - with goods and services over time" (Nickels, McHugh, \& McHugh, 2008, p. 351). Finally, "customer relationship management is an information technology system that gathers and utilizes customer information for the organization so that the organization may anticipate customer wants, need, and desires and thereby building lasting customer business relationships" (Schermerhorn, 2008, p. 88).

Although investment in the thought pattern of CRM, the question arises: does this mean that customer relationship management is the all-encompassing panacea? Will customer relationship management give the modern Internet business entrepreneur the marketing and business skills necessary to be successful? Erin Kinikin, vice-president of customer relationship management at Giga Information Group, asserted that "customer relationship management is one of the most dramatic, fundamental changes in the history of business" (as cited in Sims, 2000b, II 2). Furthermore, Harrell (2002) concisely stated the essence of customer relationship management:

The heart of the marketing concept is to address customer needs and wants. It does not stop there. Customer needs and wants should be addressed in a way that produces customer satisfaction and loyalty. Although not every customer seeks a relationship with every purchase, needs and wants more often are best addressed by establishing relationships. (p. 43)

It is imperative for the success of growing, Internet-based enterprises to establish an ongoing, customer-centric relationship with each customer. Skip Lefauvre, former CEO of Saturn Corporation, shared his insight about this concept by noting that "a company must do things so astonishingly well that customers become not merely loyalists but rather outright apostles" (as cited in Foster, 2001, p. 44). Connecting to customers by using CRM creates a personal bond that translates into turning each customer into an "apostle" (Foster, 2001, p. 44).

\section{Examination of CRM}

The composition of CRM includes many components, and it is a lifelong business prescription. Understanding the unique combination of components in CRM and the interrelationship of these ingredients is vital 
to successfully amassing CRM's benefits for the customer-centric organization. The first course of action in accomplishing this task is to dissect and define CRM. CRM is a business model; a business strategy; and a prudent business practice whose principal goal is the identification, anticipation, and understanding of all of an organization's future and current customers. The primary goal of CRM is to maximize the relationship between an organization and its customers, and to take care of the customers. CRM enables a company to forge and integrate itself into the buying practices of consumers, all the while creating a tight bond and connection with them. CRM means the creation of a long-term, mutually beneficial business relationship between an organization and its customers, where the organization may intimately know and serve every customer, in addition to understanding and anticipating the wants and needs of current and future customers.

CRM is a customer-centric business strategy that asserts that customers are an asset that must be managed successfully throughout the entire customer life cycle. According to CRM best practices, CRM is all about finding, knowing, and delighting customers. CRM should transform an organization's customer relationships and customer interactions into an atmosphere reminiscent of a friendly, small-town American corner store (Blodgett, 2000; Bresnahan, 1998; Fickel, 1999; Foster, 2001; Kalakota \& Robinson, 1999; Sims, 2000a, 2000b; Thompson, 2000b, 2000c).

The design of a CRM system uses technology to track, coordinate, and integrate marketing, organizational sales, outstanding orders, customer-organization interactions, service and repair, customer service, and unresolved problems. In addition, a CRM system should facilitate the integration of all of the organization's systems from the top to the bottom of the organization, including, but not limited to, the supply chain, internal and external customers, stakeholders, and the labor needs of the organization. The creation of a CRM system should focus on the customers and should place the customers at the initial point of design.

Customer-centric organizations target new customers, acquire new customers, and convince new customers to purchase or obtain their product(s). They use CRM technology to capture new customer data; combine them with external and internal sources; and consolidate them into a central information database, which adds intelligence to the organization. CRM is dependent on the capture, storage, and analysis of all customer-related data used to deliver personalized service to the customers (Blodgett, 2000; Bresnahan, 1998; Fickel, 1999; Foster, 2001; Kalakota \& Robinson, 1999; Sims, 2000a, 2000c; Thompson, 2000b, 2000c).

\section{The Crux of the Matter}

The retail industry revolves around the customer more than any other industry. It becomes imperative to do more than just interact with the customer in an effective and efficient manner, but also to "know" the customer. Knowledge about the customer and about the current business environment (internal and external) delivers increased profits, market share, and customer loyalty. (Rao \& Raparia, n.d., II 1)

CRM and the implementation of customercentricity translate into three core proficiencies: communication and codification of pertinent and relevant 
information; efficient codification of the information, thus transforming it into data; and knowledge management and effective utilization of that knowledge. According to Exact Software North America (2002), "Ecustomer relationship management is an essential tool for effective, goal-oriented account management and sales automation" (p. 8). A. T. Kearney Company also disseminated the following message: "Customer relationship management will be the one piece of the business landscape that will differentiate successful companies from the pack. It is the one thing that will enable leading businesses to maintain or expand their profit margins" (as cited in Gorsage \& Haas, 2003, II 3).

\section{Communication}

Communication is the foundation of CRM. CRM systems and access to CRM tools unlock the mysteries of consumer behavior (Rao \& Raparia, n.d.). Communication between customers and corporations is the mining place of raw information. Codification of the raw information into the CRM system translates into customer analytics that facilitate effective knowledge management. Wipro Technologies explained this concept rather succinctly:

Customer analytics studies details, regarding the customer from data gathered in the course of their interaction with the retailer. The loyalty of the customer to the company/business is gained by rendering improved services and streamlining the organizations processes. In essence, Customer Analytics attempts to correlate demographical data, product data, and services data. (as cited in Rao \& Raparia, n.d., II 5)

These customer analytics are essential for success in retail business because they give retailers the ability to take the pulse of their customers. With these customer analytics, retailers have information on the customer base, demographics, and behavior characteristics. Armed with these data, knowledge management and data mining may facilitate informed decision making for restructuring organizations' marketing strategies on pricing, location, and assortment to accomplish true competitive advantage in the marketplace or the marketspace (Rao \& Raparia, n.d.).

Many sources of customer data are available, the most obvious being contact between retailers and consumers either during the initial sale or when a customer service interaction occurs. Some additional sources of customer data include the following:

Retailer "loyalty programs" and rewards cards, consumer registrations, data gathered from Debit Card/Credit Cards, syndicated data such as Axiom and Claritas databases, customer registrations forms on the organizations web site, click stream data from web logs and revisits to websites, point of sale data, personalized delivery services and finally, mail order catalogs (Rao \& Raparia, n.d., II 6)

After the initial gathering and codification of the data, it becomes merely a function of knowledge management and data mining. The knowledge management and data mining part of this algorithm is where the information becomes the analytics for marketing (i.e., customer segmentation, target marketing, and campaign management; application areas for customer analytics, including new product introduction and customer/channel affinity); 
sales (i.e., customer profitability analysis, cross-selling and up-selling, market basket analysis, and product affinity); and customer service (customer satisfaction analysis and customer loyalty analysis).

\section{E-communication}

Communication is fundamental to success in the virtual learning organization. In short, CRM means communication. Sims (2000b) reiterated this very concept of CRM being communication centric and customer centric:

Like all management philosophies, customer relationship management fundamentally has one simple purpose - making your organization more profitable, which it does by ensuring your customers stick around longer. Ideally, customer relationship management gets customers to do more business with you because they like how you take care of them. Proper customer relationship management should cut costs, reduce irritation among customers and recipients, and it should encourage clients to communicate more of their desires for your organization to meet. In other words, successful business and customer relationship management is all about communicating useful business information. (p. 2)

The establishment of a CRM process must be examined, analyzed, and strategically implemented by all of the involved parties, and all of the stakeholders must be committed to the change that will take place within the organization. Finally, if all moves forward, and if the participants perceive the value of CRM and find professional gratification or reward within the confines of a culture that embraces not only the technology but also the philosophy of CRM, then competitive advantage can become a reality through increased customer satisfaction, increased revenue generation, and significant growth in productivity. The use of CRM will make the organization ready to compete effectively in a customercentric, virtual environment.

\section{E-vision}

Visionary leaders recognize and understand that the changes rippling throughout the business landscape are the consequence of the influence of e-business and e-commerce. The power shift has gone directly from the product-centric, or product-focused, environment to the customer-centric, or customer-focused, environment (Seybold \& Marshak, 1998). The consumer now has garnered the power to dictate exactly which businesses will be patronized and which businesses may succeed or fail (Sims, 2000b). Customers have the power to choose where they spend their money, and when business decisions are made, the differentiation between one e-business and another will be exemplary service.

\section{Adoption of CRM}

Understanding the concepts behind the utilization of effective CRM is only part of the holistic prescription. Examination, analysis, and strategic implementation are essential to business success utilizing the concepts of CRM. This means examining internal business practices, company culture, procedural processes, and information management practices, along with company knowledge management strategies and procedures.

CRM best practices demand executive leadership, thorough planning, executive 
staffing, and a realistic implementation approach. Ideally, these best practices should be implemented in conjunction with an exemplary technology plan and supplemented by a committed team of members. This committed team should be comprised of a visionary leader, team associates who are psychologically committed to the cause, and solution providers who partner the cause. Vendors and supplies consider themselves partners and act as partners, not just another cog in the wheel composed of many vendors or suppliers (Thompson, 2000a). Thompson recommended the following five best business practice steps for the effective business implementation of CRM:

Practice1: The business executive who formally sponsors the project provides direction for the accomplishment of specific business goals while resolving critical issues.

Practice 2: The project team performs a thorough analysis of short- and long-term requirements, soliciting input from key stakeholders, especially from channel partners.

Practice 3: Project teams select solution partners, based on the strength of the solution partners' technology and commitment to services and support.

Practice 4: A project manager staffs the team with competent and committed professionals who have expertise in all critical functional and technical areas.

Practice 5: A project team implements a pilot or prototype first and then rolls out tested and successfully proven program applications in phases as appropriate to the growth of the organization. (pp. 3-4)
These are but a few of the new customercentric tools born of technology and cyberspace. These new tools enable a business to differentiate itself from the pack through the adept utilization of CRM. These tools are specifically the tools of CRM, and they are definitely worth the research, consideration, and time of the visionary leader.

\section{SUMMARY}

In the competitive global village, an organization must become customer centric and remain customer centric if it is to succeed and survive. The organization must be responsive to the customers, and the organization not only must provide customers with what they need, want, value and desire but also anticipate the needs, wants, and desires of the customers, and be prepared to deliver before the customers even know of their needs, wants, or desires.

If organizations cannot examine their current culture, the status of their own customer centricity, and the status of their own CRM, then positive change may never occur because organizations will not know where they currently stand, they cannot decide when change is needed, and they cannot speak to the degree of that change.

Toffler contended, "Change is avalanching upon our heads, and most people are grotesquely unprepared to cope with it" (as cited in Bridges, 1980, p. 4). Researchers have asserted that this statement is more relevant today than when Toffler first penned these prophetic words. The reality of social constructs and apparent culture are created by, impacted by, and tainted with the historical biases, discriminatory tendencies, myopic experiences, and focal points of the past, all of which include human perceptions, human experiences, human 
frailty, and cultural reality.

The historical recording of reality and culture are the foundation upon which current reality is structurally constructed. Without an imposed understanding of the past, the current world and the future world cannot be interpreted, understood, managed, or even conceived. 


\section{REFERENCES}

1. Bartleby.com (1996). The Columbia world of quotations. Retrieved March 27, 2009, from http://www.barleby.com/66/2/4602.h tml/

2. Blodgett, M. (2000). Masters of customer connection. CIO Magazine. Retrieved March 27, 2009, from http://www.cio.com/archive/081500_ overview_content.html

3. Bresnahan, J. (1998) Improving the odds. CIO Magazine. Retrieved March 27, 2009, from http://www.darwinmag.com/read/arc ive/111598_market_content.html

4. Bridges, W. (1980). Transitions: Making sense of life's changes. Cambridge, MA: Perseus Books.

5. Center for Management Information Technology. (n.d.). Bio - Pat House. Retrieved March 27, 2009, from http://www.commerce.virginia.edu/c mit/activities/Pat\%20House\%20Bio. html

6. Creswell, J. W. (1998). Qualitative inquiry and research design: Choosing among five traditions. Thousand Oaks, CA: Sage.

7. Daft, R. L. (2003). Management $\left(6^{\text {th }}\right.$ ed.). Mason, $\mathrm{OH}$ : Thomson SouthWestern.

8. Dickie, R. J. (1998). Customer relationship management: 1998 state of the marketplace review. Boulder, CO: Insight Technology Group.

9. Exact Software North America. (2002). Working together more efficiently: E-synergy and its effect on how we do business. Retrieved March 27, 2009, from http://www.wp.bitpipe. com/ resource/org_1020863906_193/exact .pdf

10. Fathy, N. (1999). E-commerce: All about customer relationship

management electronic commerce.

Retrieved from

http://www.suite10.com/article.cfm/e lectonic_commerce /16952

11. Fetterman, D. M. (1998). Ethnography: Step by step ( $\left.2^{\text {nd }} \mathrm{ed}.\right)$. Thousand Oaks, CA: Sage.

12. Fickel, L. (1999). Know your customer. CIO Magazine. Retrieved March 27, 2009, from http://www/ darwinmag.com/read/archive/081500 _customer_content.html

13. Fleischmann, M., \& Strauss, W. (2005). Trailer of the opening of "eCulture Factory." Retrieved March 27, 2009, from http://netzpannung.org/cat/servlet/Ca tServlet?cmd=netzkollektor \&sub Command=showEntry\&entryld $=373$ 003\&lang=en

14. Foster, S. T. (2001). Managing quality: An integrative approach. Upper Saddle River, NJ: Prentice Hall.

15. Galbraith, J. R. (2005). Designing the customer-centric organization: A guide to strategy, structure, and process. San Francisco: Jossey-Bass.

16. Gorsage, M., \& Haas, R. (2003). CRM: Moving toward customer value management. Executive Agenda, VI(1). Retrieved March 27, 2009, from http://www.atkearney.com/main.taf? $\mathrm{p}=5,1,1,63$

17. Hagel, J., III, \& Armstrong, G. (1997). Net gain: Expanding markets through virtual communities. Boston: Harvard Business School Press.

18. Harrell, G. D. (2002). Marketing: Connecting with customers ( $\left.2^{\text {nd }} e d.\right)$. Upper Saddle River, NJ: Prentice Hall.

19. Kalakota, R., \& Robinson, M. (1999). E-business: Roadmap for 
success. Boston: Addison Wesley.

20. Kanter, R.M. (1983). The change masters: Innovation and entrepreneurship in the American Corporation. New York: Simon \& Schuster.

21. Kanter, R. M. (2001). Evolve!: Succeeding in the digital culture of tomorrow. Boston: Harvard Business School Press.

22. Khan, A., \& Conte, J. (n.d.). Impressionist art. Retrieved March 27, 2009, from http://longwood. cs.ucf. edu/ MidLink/Impress.html

23. Kocourek, P., Hyde, P., Jones, J., Tipping, A., Egon, M., \& Ribeiro, F. (2004). The customer-centric organization: From pushing products to winning customers. Retrieved March 27, 2009, from http://www.boozallen.com

24. Laudon, K. D., \& Guerico Traver, C. (2007). E-commerce: business, technology, society $\left(3^{\text {rd }}\right.$ ed. $)$. Upper Saddle River, NJ: Prentice Hall.

25. Nickels, W. G., McHugh, J. M., \& McHugh, S. M. (2008).

Understanding business ( $8^{\text {th }}$ ed.). Boston: McGraw-Hill Irwin.

26. Rao P. S., \& Raparia, P. K. (n.d.). Know your customer: An approach note. Retrieved March 27, 2009, from http://www.wipro.com/insights/know yourcustomer.htm

27. Robbins, S. P., \& Judge, T. A. (2007). Organizational behavior $\left(9^{\text {th }}\right.$ ed.). Upper Saddle River, NJ: Pearson: Prentice Hall

28. Robson, C. (2002). Real world research: A resource for social scientists and practitioner researchers $\left(2^{\text {nd }}\right.$ ed.). Malden, MA: Blackwell.

29. Schermerhorn, J. R., Jr. (2008). Management $\left(9^{\text {th }}\right.$ ed.). Hoboken, $\mathrm{NJ}$ :
John Wiley \& Sons.

30. Scott, W. R., \& Davis, G. F. (2007). Organizations and organizing:

Rational, natural, and open system perspectives. Upper Saddle River, NJ: Pearson.

31. Senge, P. M. (1990). The fifth discipline: The art and practice of the learning organization. New York: Doubleday.

32. Seybold, P., \& Marshak, R. (1998). Customers.com. New York: Random House.

33. Sims, D. (2000a). The future of CRM: Same, but different. Retrieved March 27, 2009, from http://www.CRMguru.com/content/f eatures/sims06.html

34. Sims, D. (2000b). A new ROI for new economy CRM: And just why doesn't high-tech get it? Retrieved March 27, 2009, from http://www.CRMguru.com/content/f eatures/sims02. html

35. Sims, D. (2000c). What is CRM? Retrieved March 27, 2009, from http://www.CRMguru. com/content/features/sims01.html

36. Sweat, J. (1999). Why Siebels matters: While others focus on insanely great software, Siebel Systems is winning with customercentric values. Retrieved March 27, 2009, from http:www.informationweek.com/757 /Siebel.htm

37. Thompson, B. (2000a). Getting the most out of channels with ePartner: Best practices. Retrieved March 27, 2009, from http://www.CRMguru.com/content/f eatures/ thompson03.html

38. Thompson, B. (2000b). Partner relationship management: A critical e-business strategy for a multichannel world. Retrieved March 27, 
2009 , from

http://www.CRMguru.com/

content/features/thompson02.html

39. Thompson, B. (2000c). A realistic

view on customer relations.

Retrieved March 27, 2009, from

http://www.CRMguru.com/content/f

eatures/thompson03.html

40. Van Maanen, J. (1988). Tales of the

field: On writing ethnography.

Chicago: University of Chicago

Press.

41. Wreden, N. (2005). HBR: Building

the customer-centric organization.

Retrieved March 27, 2009, from

http://fusionbrand.blogs.fushionbran

d/2005/05/hbr_building/th.htm 1 